passing through Iceland spar (calcite); and in the same year the law of constancy of interfacial angles was proposed by Steno (Steensen) from his measurements of quartz crystals. The first definition of crystallography as a new science appeared in Romé de l'Isle's Essai, published in Paris in 1772; and he taught the first course on crystallography there from about 1783 . An example of international activity is the derivation (from 1880 to 1884 ) of the 230 crystallographic space groups by Fedorov (St Petersburg), Schoenflies (Göttingen) and Barlow (London). Often what had seemed to be only of academic interest has later become of practical importance.

Crystallography is also interdisciplinary, making major contributions to biology, chemistry, metallurgy, mineralogy and physics. It has developed rapidly since the discovery in 1912 of the diffraction of $\mathrm{X}$ rays by crystals. In Munich at that time, Wilhelm Röntgen was Head of the Institute for Experimental Physics, Arnold Sommerfeld was Head of the Institute for Theoretical Physics and Paul von Groth was Head of the Institute for Mineralogy and Crystallography. These three intellectual giants, together with their assistants and graduate students, customarily met after lunch for coffee and cakes at the Café Lutz in the Hofgarten. Into this creative atmosphere came Max von Laue, Paul Ewald (who was writing his doctoral thesis on diffraction), Walter Friedrich (Sommerfeld's assistant) and Paul Knipping (a graduate student of Röntgen). As is well known, Friedrich and Knipping performed the first X-ray diffraction experiment under von Laue's general supervision; but the location of the atoms in the crystal structures was performed in England by the fatherand-son team of William Henry Bragg and William Lawrence Bragg. Thus the subject of crystal structure analysis began (in 1913) and over the years this has contributed immensely to our understanding of minerals, metals, proteins, enzymes and viruses.

Throughout the history of crystallography, success in instrumentation has gone hand-in-hand with developments of relevant theory; and in the last fifty years, advances have been made with the help of ever-increasing computational power. The Historical Atlas of Crystallography tells the stories of these developments, through the time maps and the individual chapters; and by copious references to the sources. The Atlas will be of interest not only to crystallographers but also to historians of chemistry, mineralogy and physics. Indeed, it will surely become a paradigm on which future texts will be modelled.

Moreton Moore is in the Department of Phys ics, Royal Holloway and Bedford New College, University of London, Egham, Surrey, TW20 OEX, UK

\section{Cultural exchange}

Robert M. Macnab

Physiology of the Bacterial Cell: A Molecular Approach. By Frederick C. Neidhart, John L. Ingraham and Moselio Schaechter. 1990. Pp. 506. United States, Sinauer: \$43.95; Britain, Freeman $£ 34.95$.

GROWTH, although certainly a fundamental activity, is not the only one bacteria undertake. Physiology of the Bacterial Cell, which has evolved from a previous book titled Growth of the Bacterial Cell (Sinauer, 1983), wisely acknowledges this fact and includes treatment of such topics as chemotaxis, cellular differentiation and ecology, as well as the previous thorough treatment of cell composition, structure, assembly, metabolism and growth.

The authors take Escherichia coli as their "reference cell", and for data and references draw heavily from the now standard two-volume text Escherichia coli and Salmonella typhimurium: Cellular and Molecular Biology by J. L. Ingraham et al. (American Society for Microbiology: 1987). But they do make a real effort on each topic to give at least some indication of how other species go about their business. Also, the book does not claim to provide a broad description across the microbial world' (a description that is already available in an existing book under that title by Ingraham and coauthors).

Intended mainly for upper undergraduate or graduate students, but also useful as a reference source for others, Physiology of the Bacterial Cell is written by three masters in the art of communicating in a fashion that is simple and lucid without being condescending. It is informative and up-to-date, providing an appropriate level of detail for a survey book and pointing the reader to more detailed treatments elsewhere. The authors make extensive and effective use of numerical values and calculations concerning all aspects of the cell's existence, such as the number of molecules of various sorts that the cell contains, or the error rates and costs of correction associated with the successive stages of gene expression. The book is well illustrated, striking a happy balance between reaction schemes, skilfully drawn cartoons of processes such as membrane assembly, and light and electron micrographs.

The reader is first introduced to the bacterial cell from the point of view of its chemical composition, and is then given a survey of its ultrastructure. The treatment of metabolism, by the authors' own admission, follows an unconventional order, starting with synthesis and assembly of macromolecules (DNA, proteins) and macromolecular complexes (cell membranes, flagella), then continuing with the synthesis of small molecules, and finishing with what is usually the starting point, the main catabolic ("fueling") pathways of the cell; this order presented no problems for me, and would probably present none even to an inexperienced reader. Acquisition of food, both in the sense of seeking it out (chemotaxis) and taking it up (active transport) are given treatment in a separate chapter.

The remainder of the book deals principally with growth, regulation of metabolic activity (at the level of enzyme activity and gene expression) and genetic adaptation. Here, even though each individual chapter reads clearly enough, the overall organization could be improved. For example, a chapter on growth of cells and populations is separated from chapters on the cell cycle and on growth rate by several chapters on unrelated material such as genetic adaptation.

Overall, this is a commendable book that should be a pleasure to read for the student interested in getting a broad introduction to bacterial physiology.

Robert M. Macnab is in the Department of Molecular Biophysics and Biochemistry, P.O. Box 6666, 260 Whitney Avenue, New Haven, Connecticutt 06511, USA.

\section{Copies of articles from this publication are now available from the UMI Article Clearinghouse.}

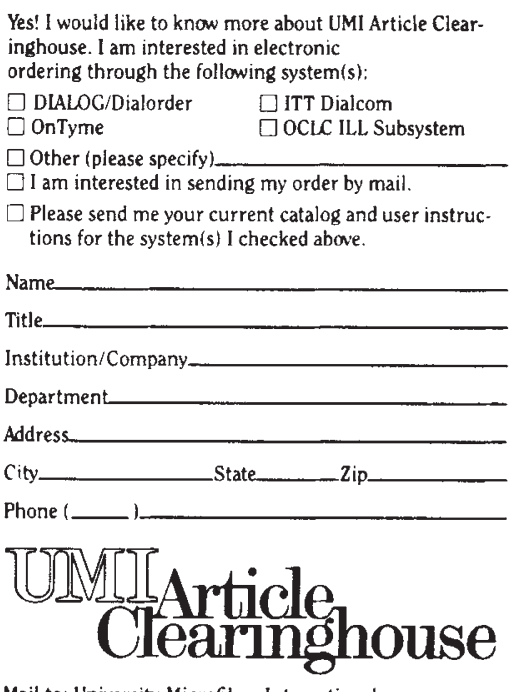

Mail to: University Microfilms International

300 North Zeeb Road, Box 91 Ann Arbor, MI 48106 